\title{
Growth Factor Receptor-Bound Protein 14
}

National Cancer Institute

\section{Source}

National Cancer Institute. Growth Factor Receptor-Bound Protein 14. NCI Thesaurus.

Code C26230.

Growth factor receptor-bound protein $14(540 \mathrm{aa}, \sim 61 \mathrm{kDa}$ ) is encoded by the human GRB14 gene. This protein plays a role in the regulation of signaling from both the insulin receptor and the insulin-like growth factor receptor. 